\title{
Variability in the immunogenic preS region of Pakistani hepatitis $B$ virus isolates
}

\author{
Saima Iftikhar ${ }^{1} \cdot$ Muhammad $_{\text {Akhtar }}{ }^{1}$
}

Received: 2 January 2019/Accepted: 13 March 2019/Published online: 15 June 2019

(C) Indian Virological Society 2019

\begin{abstract}
This paper reports the genetic variability of hepatitis B virus in Pakistan population. The worldwide prevalence of hepatitis B virus is estimated to be around 350 million that causes significant mortality especially in developing countries like Pakistan. In this study, genetic diversity of HBV was checked by using preS domain of HBV. About seventy-five samples were selected for study. Among these samples nine samples showed positive results after PCR and gel analysis. These nine samples were named SBS001-SBS008. After gel purification these samples were ligated in T/A cloning vector and transformed with $E$. coli DH5 $\alpha$. After successful cloning and positive restriction analysis these samples were subjected to DNA sequencing. Sequencing results showed that eight samples (SBS002-SBS008) have a deletion of 33 nucleotides at $\mathrm{N}$-terminal that is characteristics of genotype $\mathrm{D}$ while SBS001 belongs to genotype C. Silent mutations and amino acid changes were also searched in this highly variable region of genome. Based upon this study it was concluded that genotype $\mathrm{D}$ is the most common genotype in Pakistan.
\end{abstract}

Keywords Hepatitis B virus - DNA - T/A cloning vector · E. coli $\mathrm{DH} 5 \alpha \cdot$ preS domain

Saima Iftikhar

saima13pu@gmail.com

1 School of Biological Sciences, Quid-e-Azam Campus, Punjab University, Lahore, Pakistan

\section{Introduction}

Hepatitis B is a major cause of mortality worldwide with 257 million chronically infected subjects, and the foremost cause for hepatocellular carcinoma (HCC) worldwide [17]. According to The World Health Organization (WHO) approximately 240 million people have chronic HBV infection [19]. In Pakistan, there are estimated 7-9 million carriers of hepatitis B virus (HBV) with a carrier rate of $3-5 \%[7,13]$.

Hepatitis B virus belongs to family of related DNA viruses called the hepadnaviruses. The viral genome of HBV is a partially double stranded DNA of approximately $32.00 \mathrm{bps}$ [15]. The genome encodes four overlapping open reading frames, which results in the transcription and expression of seven different hepatitis B proteins. The surface gene, codes for three proteins L (Large), M (medium) and $\mathrm{S}$ (major or small) protein. These proteins are the products of same gene with translation occurring from different methionine residues. The surface gene can be studied through its full-length translation product (L protein) or in its various parts (pre S1, pre S2, S). preS1 and preS2 regions of DNA are collectively called preS and in vitro translated peptides corresponding to these DNA sequences are called preS protein. There are at least eight genotypes A to D with 121 strains of HBV. Immigration also contributes in the spread of new HBV genotypes in patients with acute hepatitis [3].

The DNA sequences of the PreS region alone are enough for the classification of HBV into different subgroups. The preS region is the most hypervariable among all regions of Hepadnavirus genome. The product of this gene plays a role in species specificity of HBV and involved in attachment of HBV to hepatocytes. The development of mutations in the preS region result in the 
production of escaped mutants that are no more neutralized by anti hepatitis B antibodies and are capable of dodging the immune response induce by $\mathrm{HBV}$ vaccines. Point mutations as well as deletions have also been reported in preS region of HBV genome [4]. Mutations of preS regions are associated with persistent $\mathrm{HBV}$ infection leading to chronic HBV infection and hepatocellular carcinoma. Mutations in preS and $S$ regions may affect the sensitivity of antigen antibody test routinely used to detect hepatitis B antigen in sera. Besides this occurrence of escape mutants are also present in unvaccinated population [5].

\section{Materials and methods}

\section{Chemicals and kits}

All chemicals used in this study were originated from SIGMA (USA), Merck (Germany), Fluka (Switzerland), Fisher Scientific (USA), All designed primers were synthesized by integrated DNA Technologies, on order by e-oligos (a brand of Gene Link, Inc.), Hawthorne, NY10532. TA Cloning vector, pTZ 57R/T, InsTAclone TM PCR Cloning Kit \#K1214 and DNA Extraction Kit \#K0513 were obtained from Fermentas Life Sciences. All other cultivation media and bulk chemicals were purchased from Difco laboratories, US Biological (CA, USA).

\section{Sample collection and PCR primer designing}

Hepatitis B surface antigen (HBSAg) positive DNA samples were collected from different laboratories having facilities of HBV diagnostic tests by PCR (polymerase chain reaction) from various locations scattered widely in different parts of Pakistan so that they could imitate the distribution of HBV genotype in our country. All the patient were having chronic hepatitis B with elevated level of aminotransferase and have not gone any kind of treatment yet (Table 1). All the patients signed an informed consent and the study was approved by institutional ethics committee. The collected DNA samples were carefully stored at $-20{ }^{\circ} \mathrm{C}$ for further use in PCR. Two pairs of gene specific primers were designed. The first pair of primer (HbSF1, HbSR1) was used to amplify conserved $1.1 \mathrm{~kb}$ fragment containing preS region of surface gene. Second set of primer (PSF, PSR) was used to amplify the preS region of $0.58 \mathrm{~kb}$ (Table 2).

\section{PCR amplification and agarose gel electrophoresis}

PCR mixture prepared in $0.5 \mathrm{ml}$ PCR tubes placed on ice and $50 \mu \mathrm{l}$ amplification reaction mixture contained $1 \mu \mathrm{l}$ of forward and reverse primers $(100 \mathrm{pmol})$, with $5 \mu \mathrm{l}$ of $1 \mathrm{X}$ PCR buffer $\left(75 \mathrm{mM}\right.$ Tris-Cl pH 8.8 at $25{ }^{\circ} \mathrm{C}, 20 \mathrm{mM}$ $\left(\mathrm{NH}_{4}\right)_{2} \mathrm{SO}_{4}$ and 0.01 Tween 200), $3 \mu \mathrm{l}$ of $\mathrm{MgCl}_{2}(2.5 \mathrm{mM})$, $5 \mu \mathrm{l}$ of dNTPs (dATPs, dGTPs, dTTPs and dCTPs) mixture $(0.2 \mathrm{mM}), 1 \mu \mathrm{l}$ of Taq DNA polymerase (2.5 units) and $10 \mu \mathrm{l}(100 \mathrm{ng})$ of DNA. Final volume was made to $50 \mu \mathrm{l}$ using PCR grade water. Amplification was carried out in thermal cycler (AB Applied Biosystem 2720) at $94{ }^{\circ} \mathrm{C}$ for $2 \mathrm{~min}$ followed by 30 amplification cycles of $30 \mathrm{~s}$ at $94{ }^{\circ} \mathrm{C}$, $30 \mathrm{~s}$ at $50{ }^{\circ} \mathrm{C}$ and $1 \mathrm{~min}$ at $72{ }^{\circ} \mathrm{C}$ and a final incubation of 5 min at $72{ }^{\circ} \mathrm{C}$. The amplified fragment was analyzed on $1 \%$ agarose gel and DNA separation was based on size difference.

\section{Cloning of amplified DNA}

$30 \mu \mathrm{l}$ of ligation mixture contained $3 \mu \mathrm{l}$ of $1 \mathrm{X}$ ligation buffer $\left(40 \mathrm{mM}\right.$ Tris- $\mathrm{Cl} \mathrm{pH} 7.8$ at $25{ }^{\circ} \mathrm{C}, 10 \mathrm{mM} \mathrm{MgCl}_{2}$, $10 \mathrm{mM}$ DTT and $5 \mathrm{mM}$ ATP), $3 \mu \mathrm{l}$ of cut pTZ57R/T vector (200 ng), $10 \mu \mathrm{l}$ of PCR product ( 500 ng), $1 \mu \mathrm{l}$ of T4 DNA ligase (5 units) and $13 \mu \mathrm{l}$ of PCR grade water. The contents were incubated over night at $22{ }^{\circ} \mathrm{C}$. The control containing the circular plasmid with insert and circular plasmid without insert were also incubated in parallel with the experimental ligation mixture. Then the ligation mixture was used to transformed competent cells of E. coli DH5a.

\section{Restriction analysis}

Single digestion with specific restriction endonuclease was performed to confirm the cloning in plasmid vectors. For restriction, the $30 \mu \mathrm{l}$ reaction mixture contained $1-1.5 \mu \mathrm{g}$ of recombinant plasmid, 10 units of Hindl11 in $1 \mathrm{X} \mathrm{R}$ buffer. The reaction mixture was incubated at $37^{\circ} \mathrm{C}$ for $3 \mathrm{~h}$. After the required incubation period the sample were run on $1 \%$ agarose gel and analyzed under UV light after staining with ethidium bromide.

\section{DNA sequencing}

Sequencing was carried out to characterize the preS domain of Pakistani HBV isolates. Plasmid DNA isolated
Table 1 Clinical Characteristic of patients included in this study

\begin{tabular}{llllll}
\hline Characteristics & Number & Age (year) & ALT (IU/L) & AST (IU/L) & Viral load (log10 IU/ml) \\
\hline Male & 40 & $30 \pm 25$ & $110 \pm 170$ & $103 \pm 200$ & $3.65 \pm 1.50$ \\
Female & 35 & $40 \pm 15$ & $106 \pm 300$ & $100 \pm 270$ & $4.5 \pm 1.26$ \\
\hline
\end{tabular}


Table 2 The primers used for study are as follows

\begin{tabular}{llll}
\hline Primer & Sequence $\left(5^{\prime}-3^{\prime}\right)$ & Restriction site & Expected size \\
\hline HbSF1 & $5^{\prime}$ GTCCCCTAGAAGAAGAACTCCCTC & No & $1.1 \mathrm{~Kb}$ \\
HbSR1 & 5' CCCTAGAAAATTGAGAGAAGTCCA & & \\
PSF & $5^{\prime}$ TCTACCATATGGGAGGTTGGTCTTCCAAACC & Nde 1 & $560 \mathrm{bp}$ \\
\hline
\end{tabular}

from positive transformants was subjected to sequence analysis on ABI PRISM 310 automated capillary genetic analyzer. Sequencing was performed both in the forward and reverse directions using M13 universal primers. Following DNA sequencing, newly sequenced DNA samples were aligned with adr sequence (Ac. No. AB246345) and ayw sequence (Ac. No. X65259). The alignment, ORF translation and molecular mass calculation of predicted protein was carried on http://www.expasy.org and NCBI Blast software. Phylogenetic analysis of newly sequenced samples was also performed with the help of Geneious and Dendroscope softwares.

\section{Results}

\section{Amplification of the surface gene of $\mathrm{HBV}(\mathrm{Hb}-\mathrm{S})$}

In order to check for variability in gene sequences, the $\mathrm{Hb}$ $S$ gene was cloned and sequenced from 8 Pakistani patients, positive for $\mathrm{HBV}$ infection, and their DNA named as SBS001-SBS008. This gene was amplified by polymerase chain reaction (PCR) and products was resolved on $1 \%$ agarose gel electrophoresis. The primers amplified a fragment of 1.1 KB of all DNA samples from Pakistani isolates as well as control (Fig. 1a).

\section{Restriction analysis of $\mathrm{Hb}-\mathrm{S} / \mathrm{pTZ57RT}$}

Single restriction of recombinant plasmid, $\mathrm{Hb}-\mathrm{S} / \mathrm{pTZ}$ T7RT was performed with Hind111 in its recommended buffer R. After a 3-h incubation at $37{ }^{\circ} \mathrm{C}$, samples were analyzed on $1 \%$ agarose gel. Single restriction of recombinant plasmids showed a single band of $\sim 4.0 \mathrm{~kb}$ that confirmed the successful ligation to give $\mathrm{Hb}-\mathrm{S}$ in pTZ57R (Fig. 1b).

\section{Sequence variation analysis}

PreS sequences were compared with Japanese strain (adr4), AB246345 (adr serotype) and X65259 (ayw serotype) for sequence variation analysis. PreS sequence for SBS001 was found to be similar to Japanese adr4 and AB246345 with $98 \%$ homology and changes of $\mathrm{X}$ amino acids as compared to Japanese adr4. SBS001 showed one mutation $\mathrm{C}$ to $\mathrm{T}$ at position \# 62 which leads to an amino acid change from Pro to Leu (Fig. 2) and second mutation at position \# (a) $\begin{array}{llllllllll}M & 1 & 2 & 3 & 4 & 5 & 6 & 7 & 8 & 9\end{array}$

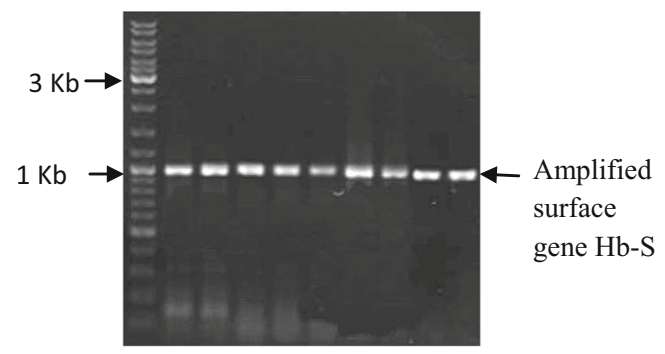

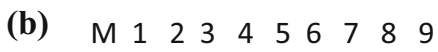

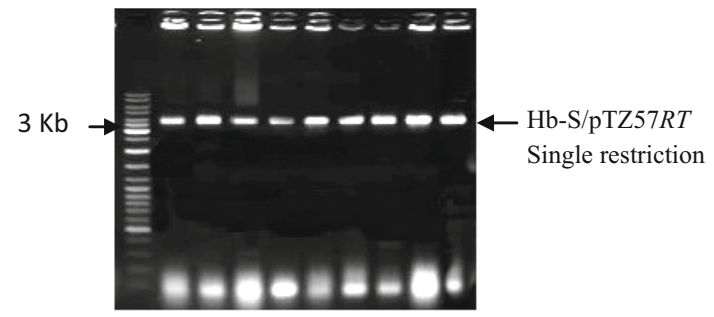

Fig. 1 a PCR amplification of Surface gene (Hb-S) isolated from Pakistani HBV Patient. M: 1 kb DNA ladder, Lane 1: PBS adr4 (Positive control), Lane 2-9: SBS001, SBS002, SBS003, SBS004, SBS005, SBS006, SBS007, SBS008 (Pakistani Patient samples). b Restriction analysis of surface gene $\mathrm{Hb}-\mathrm{S}$ of $\mathrm{HBV}$ cloned in pTZ57RT (Hb-S/pTZ57RT) with Hind111. M: $1 \mathrm{~kb}$ DNA ladder, Lane 1: PBSadr4 restricted with Hind111(positive control), Lane 2-9: SBS001, SBS002, SBS003, SBS004, SBS005, SBS006, SBS007, SBS008 restricted with Hind111

88 which results in an amino acid change from Leu to Val in an epitopic region (21-47 amino acid). SBS001 is more similar to Japanese adr4 than to AB246345, which indicates that in Pakistan HBV genotypes are very much similar to that of Japan. All other samples (SBS002, SBS003, SBS004, SBS005, SBS006, SBS007, SBS008) had a common 33 bp deletion at the N-terminal, which is characteristic of a genotype D.

In addition, SBS002, SBS003, SBS004 and SBS005 had common mutations which are: nucleotide change at postion number 431 from $\mathrm{C}$ to $\mathrm{T}$ leading to amino acid change from Leu to Pro; change at postion number 440 from $\mathrm{C}$ to $\mathrm{T}$ causing an amino acid change from Ala to Val; mutation at position number 424 from $\mathrm{T}$ to $\mathrm{A}$ changing the amino acid His to Gln and at position number 448 from $\mathrm{T}$ to $\mathrm{A}$, changing the amino acid Leu to Ile. Apart from the abovementioned mutations, SBS004, SBS005 and SBS007 were mutated at postion number 229 from $\mathrm{T}$ to $\mathrm{A}$, changing the amino acid from Val to Leu. SBS002 and SBS003 were 


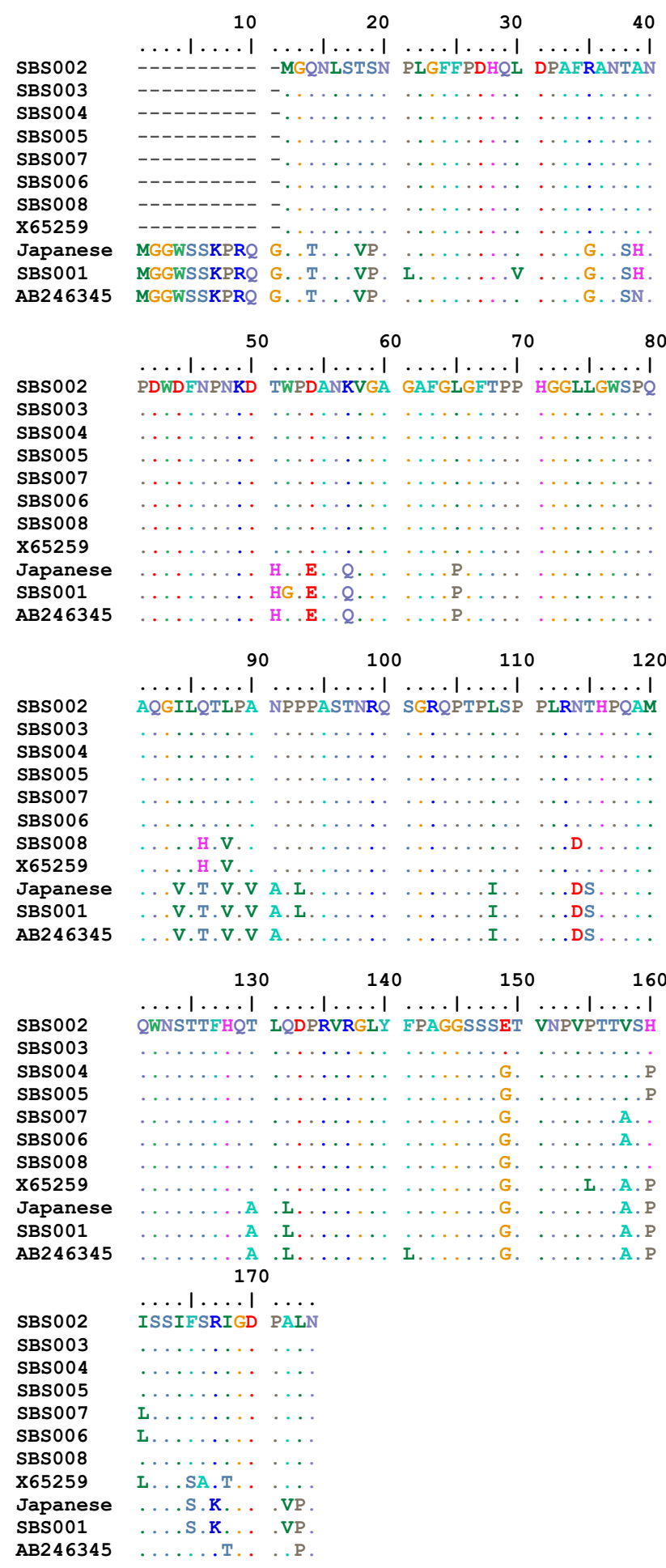

Fig. 2 Alignment of protein sequences of preS domain of Pakistani isolates (SBS001-SBS008) and a reference protein sequence (AB246345 and X65259). Japanese isolate acts as a control sequence

similar to each other as they have an additional mutation at position number 413 that leads to change of amino acid from Gly to Glu. SBS002 also showed some similar changes to SBS008 as both have three common mutations.
One at position number $441, \mathrm{C}$ to $\mathrm{A}$ that changed the amino acid from Ser to Phe. Second at position $463, \mathrm{G}$ to T, and third at position 470 from $\mathrm{C}$ to $\mathrm{T}$ that leads to amino acid change from Ala to Ser and Thr to Ile respectively. The above results show that mutations are common within the preS domain in the eight $\mathrm{HBV}$ isolates analyzed during this study (Table 3).

\section{Comparison with other genotypes}

During this study eight preS sequences obtained from Pakistani HBV isolates were subjected to analysis and comparison with commonly found genotypes in NCBI data bank. On the basis homology divergence all sequences were classified into two groups. Group I consists of single sequence i.e. SBS001 which on phylogenetic analysis clustered with genotype C, group II include SBS002, SBS003, SBS004, SBS005, SBS006, SBS007, SBS008 which were classified as genotype $\mathrm{D}$. No sequence aligned $100 \%$ to any of the already existing sequences in the database. Maximum similarity was $98 \%$ which suggested that these sequences of Pakistani HBV isolates (preS domain) were novel sequences; hence these DNA sequences were submitted to gene bank. Gene Bank database sequences' IDS are JF957160, JN165098 and JX173071-JX173076.

\section{Phylogenetic analysis}

Phlyogentic analysis was performed with the help of webbased server ClustalW (www.ebi.ac.uk/clustalw). Sequences of different sub types were collected from NCBI database and a phylogenetic tree was constructed based on HBV preS domain. Most of the samples blonged to genotype D and subtype ayw, while SBS001 was clustered with genotype C. Hence preS region was found equally effective for the detection of genotype (Fig. 3).

\section{Discussion}

Hepatitis B virus is a worldwide disease that causes $62 \%$ of all reported liver cancer. Pakistan has been rated amongst the countries with high risk of hepatitis B infection. In our country the prevalence of HBV has increased constantly due to lack of proper laboratory facilities for diagnosis and proper blood screening at the time of blood transfusion [10]. In Pakistan, lack of vaccine and high cost of drugs are hurdles in tackling the infection of HBV [11]. In northern areas the overall prevalence of HBV was 37\% in 1995 [12].

As preS domain is the most immunogenic part of HBV genome. Among the total mutations occurring in the HBV genome $50 \%$ occur in the preS domain that developed the 
Table 3 Mutations found in Pakistan HBV preS sequences compared to AB246345 and X65259

\begin{tabular}{lllll}
\hline S no. & Mutations & Nucleotide & Impact on protein sequence & Found in sequence no. \\
\hline 1 & $\mathrm{C} \rightarrow \mathrm{T}$ & 68 & Pro $\rightarrow$ Leu & SBS001 \\
2 & $\mathrm{~T} \rightarrow \mathrm{G}$ & 88 & Leu $\rightarrow$ Val & SBS001 \\
3 & $\mathrm{~A} \rightarrow \mathrm{C}$ & 115 & Asn $\rightarrow$ His & SBS001, Japanese \\
4 & $\mathrm{~T} \rightarrow$ & Trp $\rightarrow$ Gly & SBS001, Japanese \\
5 & $\mathrm{C} \rightarrow \mathrm{T}$ & 278 & Pro $\rightarrow$ Leu & SBS001, Japanese \\
6 & $\mathrm{C} \rightarrow \mathrm{T}$ & 422 & Leu $\rightarrow$ Phe & SBS001, Japanese \\
7 & $\mathrm{~T} \rightarrow \mathrm{C}$ & 494 & Phe $\rightarrow$ Ser & SBS001, Japanese \\
8 & $\mathrm{C} \rightarrow \mathrm{T}$ & 495 & Phe $\rightarrow$ Ser & SBS002, SBS003, SBS004, SBS005, SBS006 \\
9 & $\mathrm{~T} \rightarrow \mathrm{C}$ & 431 & Leu $\rightarrow$ Pro & SBS002, SBS003, SBS004, SBS005, SBS007 \\
10 & $\mathrm{C} \rightarrow \mathrm{T}$ & 440 & Ala $\rightarrow$ Val & SBS002, SBS003 \\
11 & $\mathrm{G} \rightarrow \mathrm{A}$ & 413 & Gly $\rightarrow$ Glu & SBS002, SBS003, SBS004, SBS005, SBS006, \\
12 & $\mathrm{~T} \rightarrow \mathrm{A}$ & 224 & His $\rightarrow$ Gln & SBS007, SBS08 \\
13 & $\mathrm{C} \rightarrow \mathrm{T}$ & 461 & Ser $\rightarrow$ Phe & SBS002, SBS008 \\
14 & $\mathrm{G} \rightarrow \mathrm{T}$ & 463 & Ala $\rightarrow$ Ser & SBS002, SBS008 \\
15 & $\mathrm{C} \rightarrow \mathrm{T}$ & 470 & Thr $\rightarrow$ Ile & SBS002, SBS008 \\
16 & $\mathrm{G} \rightarrow \mathrm{T}$ & 229 & Val $\rightarrow$ Leu & SBS004, SBS005, SBS007 \\
17 & $\mathrm{~T} \rightarrow \mathrm{A}$ & 448 & Leu- $\rightarrow$ Ile & SBS003, SBS004, SBS005, SBS007, SBS008 \\
\hline
\end{tabular}

interest to search for the point mutations in this region. These mutations reduce the effectiveness of diagnostic test and vaccination [8].

In our study based on the analysis of eight samples, the preS region of samples SBS002-SBS008 had a common 33 base pair (11 amino acid) deletion that is characteristic of genotype $\mathrm{D}$. The deletion being at the extreme $\mathrm{N}$-terminus of the chain does not affect the function of large protein [18]. So seven out of eight HBV positive samples belonged to genotype D by preS sequence analysis, which showed the high prevalence of genotype $\mathrm{D}$ followed by genotype $\mathrm{C}$. High prevalence of genotype D $(65.34 \%)$ followed by genotype C $(26.73 \%)$ is also reported in Pakistan [1]. In Pakistan early studies showed the high prevalence of genotype $\mathrm{C}$ with geographical distributions of various other genotypes [9]. They found that genotype $\mathrm{C}$ was the dominant genotype $(68.96 \%)$ in North West Province (N.W.F.P). Two genotypes C and D were dominant in Punjab with a rate of $39.65 \%$ and $25.86 \%$ respectively. Genotype A (68\%) was dominant in Sindh area. Later on, it was found that all the seven genotypes could be found in Asia [16]. For example, the most abundant genotype in India are genotype $\mathrm{A}$ and $\mathrm{D}$.

The predominant HBV genotype in Afghanistan was reported to be genotype D [2]. In various Asian countries the epidemiological data about HBV genotypes revealed the presence of all seven genotypes in Asia, especially the predominance of genotype D.
In addition SBS002, SBS003, SBS004 and SBS005 had common mutations, which are at the C-terminus of preS or preS2 region. These mutations are: nucleotide change at position number 431 leading the amino acid change from Leu $^{143}$ to Pro, change at nucleotide position number 440 causing the amino acid to change from $\mathrm{Ala}^{146}$ to Val. Mutation at nucleotide position number 424 changes the amino acid from $\mathrm{His}^{147}$ to Gln and at position number 448 from Leu ${ }^{149}$ to Ile. All these mutations were identified by comparing the observed sequence to the data base sequence of the same genotype.

Based on blast search all these mutations were considered novel and confined to Pakistani HBV isolates. So the geographic specificity of these mutations may not be ignored. Alignment of amino acid sequence deduced from the local HBV isolates showed that these mutations were not clustered in specific region but found evenly distributed throughout the preS region. Besides all these amino acid changes, many nucleotide changes did not reflect any variation at protein level. Mutations are primarily localized where they are not harmful as usually they are not part of any major epitope [6].

As it is clear from sequence analysis that preS region is the most variable part of the genome suggesting that preS region should be suitable for genotyping [14]. By following the procedure adopted for this research work, HBV genotypes can be worked out within a few days. 
Fig. 3 Phylogenetic analysis on the basis of protein sequences of preS domain

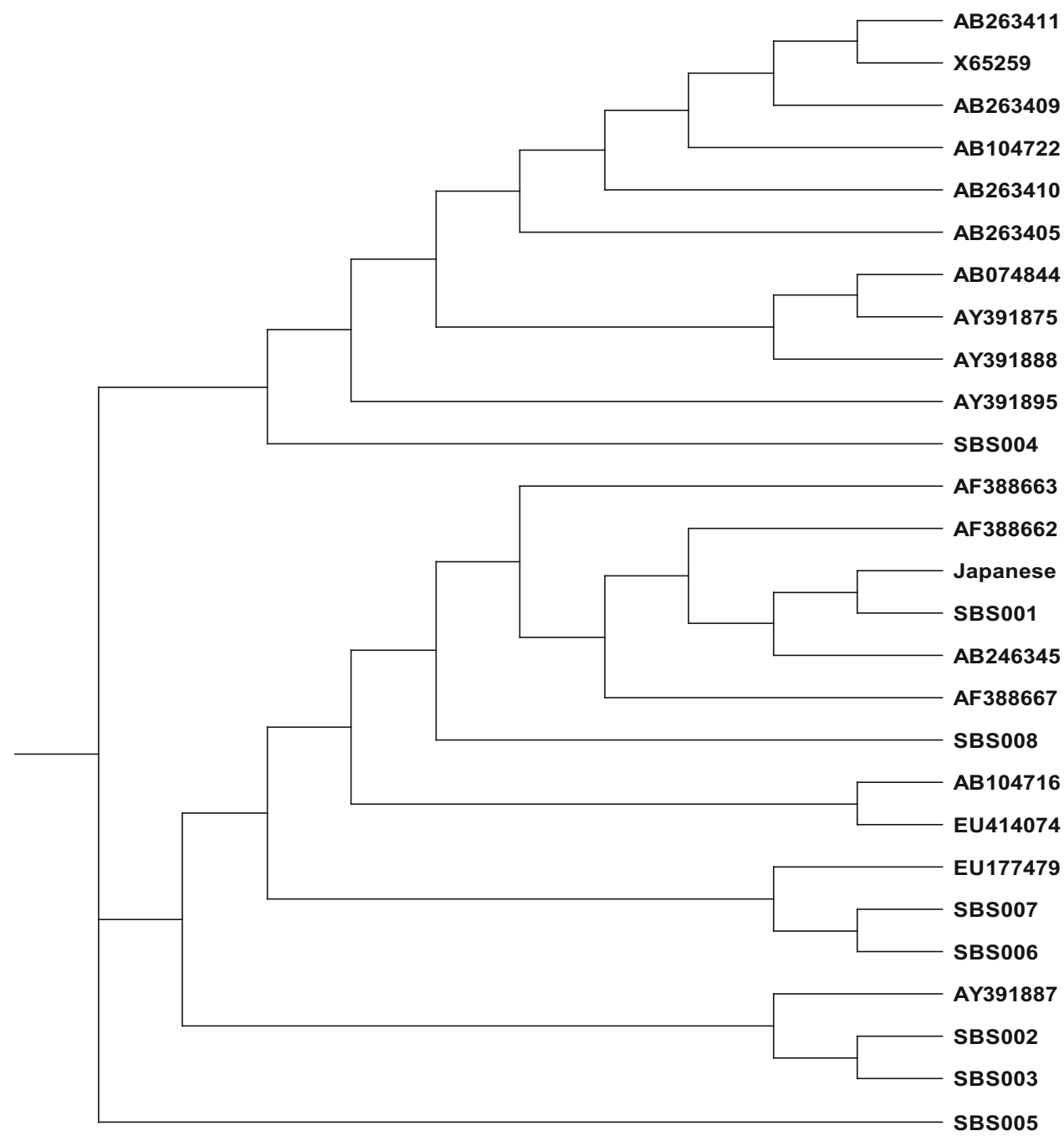

Acknowledgements I am much indebted to the Dr Altaf Khan for his help during the sequencing. I also express my great gratitude to Dr Saadat and Faisal Basheer who helped me a lot in collecting the HBV samples.

\section{References}

1. Alam MM, Zaidi SZ, Malik SA, Naeem A, Shaukat S, Sharif S, Angez M, Khan A, Butt JA. Serology based disease status of Pakistani population infected with hepatitis B virus. BMC Infect Dis. 2007;7:64.

2. Amini BOS, Alavian SM, Adeli A, Sarrami-Forooshani R, Sabahi F. Hepatitis B virus genotyping, core promoter and precore/core mutations among afghan patients infected with hepatitis B: a preliminary report. J Med Virol. 2006;78:358-64.

3. Coppola N, Sagnelli C, Pisaturo M, Minichini C, Messina V, Alessio L, Staraceet M, Signorielloal G, Gentile I, Filippini P, Sagnelli E. Clinical and virological characteristics associated with severe acute hepatitis B. Clin Microbiol Infect. 2014;20(12):O991-7.

4. Fan YF, Lu CC, Chang YC, Chang TT, Lin PW, Lei HY, Su IJ. Identification of a pre-S2 mutant in hepatocytes expressing a novel marginal pattern of surface antigen in advanced diseases of chronic hepatitis B virus infection. J Gastroenterol Hepatol. 2000;15(5):519-28.

5. Forbi JC, Ben-Ayed Y, Xia GL, Vaughan G, Drobeniuc J, Switzer WM, Khudyakov YE. Disparate distribution of hepatitis B virus genotypes in four sub-Saharan African countries. J Clin Virol. 2013;58(1):59-66.

6. Gunther S, Fischer L, Pult I, Sterneck M, Will H. Naturally occurring variants of hepatitis B virus. Adv Virus Res. 1999;52:25-137.

7. Hakim S, Kazmi S, Bagasra O. Seroprevalence of hepatitis B and C genotypes among young apparently healthy females of Karachi-Pakistan. Libyan J Med. 2008;3(2):66-70.

8. Hsu HY, Chang MH, Liaw SH, Ni YH, Chen HL. Changes of hepatitis B surface antigen variants in carrier children before and after universal vaccination in Taiwan. Hepatology. 1999;30:1312-7.

9. Idrees M, Khan S, Riazuddin S. Common genotypes of hepatitis B virus. J Coll Physicians Surg Pak. 2004;14(6):344-7.

10. Malik IA, Anwar CM, Luqman M, Ahmed A, Sarfraz T, Qamar MA. The pattern of acute viral hepatitis in children. A study based on seroepidemiology and biochemical profile. J Pak Med Assoc. 1987;37(12):314-7.

11. Malik N, Butt T, Mansoor N, Khan TG, Akbar MS, Asl M Percentage of hepatitis B and $\mathrm{C}$ among young adult males from interior Sindh. Pak Armed Forc Med J. 2008;58:260-6. 
12. Manzoor SA, Malik I, Tariq WUZ. Hepatitis B related chronic liver diseases in Rawalpindi Islamabad. J Coll Physicians Surg Pak. 1997;7:43-6.

13. Noorali S, Hakim ST, McLean D, Kazmi SU, Bagasra O. Prevalence of hepatitis B virus genotype D in females in Karachi, Pakistan. J Infect Dev Ctries. 2008;2(5):373-8.

14. Repp R, Rhiel S, Heermann KH, Schaefer S, Keller C, Ndumbe P, Lampert F, Gerlich WH. Genotyping by multiplex polymerase chain reaction for detection of endemic hepatitis B virus transmission. J Clin Microbiol. 1993;31:1095-102.

15. Stuyver L, De Gendt S, Van Geyt C, Zoulim F, Fried M, Schinazi RF, Rossau R. A new genotype of hepatitis B virus: complete genome and phylogenetic relatedness. J Gen Virol. 2000;81:67-74.

16. Toan NL, Song LH, Kremsner PG, Duy DN, Binh VQ, Koeberlein B, Kaiser S, Kandolf R, Torresi J, Bock CT. Impact of hepatitis B virus genotypes and genotype mixtures on the course of liver disease in Vietnam. Hepatology. 2006;25:1375-84.

17. Trepo C, Chan HL, Lok A. Hepatitis B virus infection. Lancet. 2014;384:2053-63.

18. Will H, Cattaneo R, Koch HG, Darai G, Schaller H, Schellekens H, van Eerd PM, Deinhardt F. Cloned HBV DNA causes hepatitis in chimpanzees. Nature. 1982;299(5885):740-2.

19. World Health Organization. Hepatitis B fact sheet. Available from: http://www.who.int/mediacentre/factsheets/fs204/en/. Accessed on 27 May 2015.

Publisher's Note Springer Nature remains neutral with regard to jurisdictional claims in published maps and institutional affiliations. 